\title{
Jnterview with Dr. Dr. b.c. Heinz Mobnbaupt, the member of International Advisory Board of Cracow Studies of Constitutional and Legal History
}

Maciej Mikula: Almost a year has passed since you received the title of Doctor Honoris Causa from the University of Zürich. How did the university contact you to tell you that they had selected you for the award? What emotions accompanied receiving it?

Heinz Mohnhaupt: The awarding of the "Dr. juris honoris causa" was a huge surprise to me. When the Dean of the Faculty of Law at the University of Zürich announced this great honour, I could not believe it. And it was only once the Dean's personal letter arrived in January 2020 that it finally seemed real. I was both elated and grateful, but I also wondered if I really deserved such an honour.

In the justification for awarding the title of Doctor Honoris Causa, your scientific achievements were mentioned. Would you like to reveal more specifically which of your numerous and erudite research papers particularly caught the attention of the University's selections committee? Were your great works on privileges in early modern Europe among them?

While the scientific papers and the topics are not explicitly mentioned in the certificate, it was my research on privileges as special forms of legislation as well as the history of comparison as a method of knowledge in various sciences from the Middle Ages to the $19^{\text {th }}$ century that was recognized in the awarding of the doctoral title. These topics included my research on the doctrine of legal sources, the conceptual history of the "constitution" and the "leges fundamentales" in Europe.

You have been associated with the Max Planck Institute in Frankfurt am Main for many years. Could I ask you under what circumstances you started working at the Institute?

I started my scientific work at the Max Planck Institute for European Legal History in 1966. The then director, Prof. Dr. Dr. h.c. mult. Helmut Coing, immediately entrusted me with the task of administrative assistant so that I had to carry out both scientific and administrative duties at the Institute until 1980. This was a very interesting and instructive time. In addition, I later served as the representative of the Institute's scientific staff 
on the Board of the Max Planck Society for six years and worked on several appointment committees of the MPS.

When you think about the numerous research projects in which you have participated, which of them do you recall as particularly interesting or absorbing? In which of them were you particularly satisfied with your participation?

In addition to my projects "Privilegia", "Constitution" and "Historical Comparison", my participation in topics of contemporary legal history was particularly interesting and important to me - in particular, the perversion of the law, on the one hand, in German National Socialism and, on the other, in the dictatorial system of Soviet Communism in the GDR and in the other Eastern European states after 1945. The dangerous relationship between politics and law has fascinated me and reinforced my conviction regarding the immeasurable value of the democratic parliamentary constitutional system. This conviction also had repercussions for my research on the importance of the European Enlightenment era.

It is well known among Polish researchers coming to the Institute that they can always count on your help, a kind word, or a friendly conversation in the university's "Sturm und Drang" restaurant. I have experienced your kindness many times first hand. Do you remember under what circumstances you met Polish researchers for the first time?

I remember very well the many legal historians and lawyers, especially from Kraków, who visited our Institute between 1968 and the early 1990s - a period spanning three directors: Helmut Coing, Walter Wilhelm and Dieter Simon. This involved working on joint projects on European legal history as well as the conviction that a common historical European legal culture exists - one that endured the political separation brought about by the "Cold War". Invitations from Polish colleagues to the Kraków Faculty of Law for lectures and symposia established a collegial and friendly relationship that has endured to this day. Among the many names, I will mention just a few: Lesław Pauli, Irena Malinowska-Kwiatkowska, Wacław Uruszczak, Stanisław Salmonowicz, Ludwik Łysiak, Dorota and Jerzy Malec, Danuta Janicka, Maciej Mikuła and many others.

\section{May I ask about your cooperation with Polish researchers? How do you evaluate} the work being done in Polish legal history?

The cooperation continued after the political change that took place in 1990, when Dieter Simon also invited Polish colleagues to a joint project on "Norm-Enforcement in Eastern European Post-War Societies (1944-1989)". This also resulted in an edited volume with contributions from Polish colleagues on Polish legal development from 1944-1989, which I supervised and edited together with Hans-Andreas Schönfeldt. Today, the work of Polish legal historians impresses with its thematic breadth and methodological openness in the international context of legal history research. It also seems remarkable to me that the wide range of research also includes medieval German legal sources in today's 
Poland and the cruel legal experiences of dictatorship from the Nazi-era and the communist dictatorship.

I also have a question that does not concern research, but please permit me to ask anyway. You are a great fan of classical music. Which composers and which pieces are the ones you listen to most often? Do you also listen to music while conducting your research work?

My favorite composers are mostly baroque: Vivaldi, Bach, Händel, Rameau, Henry Purcell and of course the "Opera of all Operas", namely Mozart's "Don Giovanni". I do not listen to this music while I work, because it always distracts me (in a positive sense) from what I should be doing.

Thank you for your time! On behalf of the Editorial Board, I wish you further fruitful research! 